\title{
VITAMIN D AND BRONCHIAL ASTHMA
}

\section{ULOGA VITAMINA D U BRONHIJALNOJ ASTMI}

\author{
Sanja Dimić Janjić', Branislava Milenkovicić,2
}

\section{Summary}

Due to its imunomodulatory properties, vitamin $D$ has a potentially growing role in chronic diseases: malignant, cardiovascular, autoimmune and chronic lung diseases. Asthma is chronic inflammatory disease of airways. Prevalence of asthma and prevalence of vitamin D insufficiency is constantly rising in past decades. According to the numerous study results we can hypothesize that vitamin D insufficiency can be important contributor to pathogenesis, stage, disease control and therapeutic response in asthma. Vitamin D has antimicrobial properties as well, because of its influence on catelicidin, human peptide produced by neutrophils, macrophages, skin, respiratory an digestive tract cells with wide antimicrobial activity (Gram-positive and Gram-negative bacteria, some viruses and fungus) (18). Recent studies provide growing evidence in favor of vitamin D supplementation in asthma.

Keywords: vitamin D, asthma, atopy, inflammation, infection

\section{Sažetak}

Zbog imunomodulatornih svojstava Vitamin D je značajan za mnoge hronične bolesti i to: maligne bolesti, kardiovaskularne bolesti, autoimunske bolesti i hronične plućne bolesti. Astma je hronična inflamatorna bolest disajnih puteva čija je prevalencija, kao i prevalencija nedostatka vitamina D, u stalnom porastu poslednjih decenija. Rezultati brojnih studija upućuju na pretpostavku da nedostatak vitamina D može biti važan činilac u patogenezi, stepenu kontrole i težini bolesti, kao i terapijskom odgovoru. Takodje, vitamin D ima antimikrobna svojstva jer deluje na katelicidin, humani peptid koji produkuju neutrofili, makrofagi, ćelije kože, respiratornog i digestivnog trakta koji ima široku antimikrobnu aktivnost (Gram-pozitivne i Gram-negativne bakterije, izvesne viruse i gljivice). Aktuelna ispitivanja sa sve većim brojem dokaza ukazuju na korist od njegove primene kod bolesnika sa astmom.

Ključne reči: vitamin D, astma, atopija, inflamacija, infekcija

\section{Uvop}

Vitamin D ili kalciferol je vitamin steroidne strukture čija se tradicionalna uloga temelji na homeostazi kalcijuma i fosfata i zdravlju muskuloskeletnog sistema. U novije vreme se sve više pažnje posvećuje imunomodulatornim svojstvima vitamina D koji ispoljava efekte na nekoliko vrsta ćelija imunskog sistema. Vitamin D je i važan regulator antimikrobnih peptida, a njegov deficit se povezuju sa nastankom respiratornih infekcija (18). Nedavno istraživanje ukazalo je da vitamin D ima ulogu u mnogim hroničnim bolestima, kao što su maligne bolesti, kardiovaskularne bolesti, autoimunske bolesti, ali i hronične plućne bolesti.

\section{METABOLIZAM Vitamina D}

Dva najvažnija oblika vitamina D su vitamin D2 (ergokalciferol) i vitamin D3 (holekalciferol). Holekalciferol i ergokalciferol se mogu uneti u organizam ishranom i dijetetskim dodacima. Mali broj namirnica je bogat vitaminom D. Dermalna sinteza vitamina $D$, naročito holekarciferola, pod dejsvom sunčevih UVB zraka, je najznačajniji prirodni izvor ovog vitamina. Stoga i ne čudi njegov široko rasprostranjen naziv „Sunčev vitamin“.

Vitamin D koji se unese hranom ili sintetiše u koži, nije biološki aktivan. Na njegov metabolizam u koži utiče sadržaj melanina u koži, starost, izlaganje suncu, procenat telesnih masti i upotreba krema za sunčanje. Apsorbuje se u tankom crevu, potom sistemskom cirkulacijom dospeva do jetre. U jetri se odvija proces hidroksilacije holekalciferola (vitamin D3) u 25-hidroksiholekalciferol, a ergokalciferola (vitamin D2) u 25-hidroksiergokalciferol. U bubrezima dolazi do hidroksilacije $25(\mathrm{OH}) \mathrm{D}$ u 1.25 dihidroksi vitamin D ili kalcitriol, biološki aktivnu formu vitamina D (22). Vitamin D i njegovi metaboliti, u plazmi se vezuju za multifunkcionalni protein nosilac vitamina D ("vitamin D binding protein"-VDBP) kojim se transportuju do ciljnih tkiva. Receptor kalcitriola ili receptor vitamina $\mathrm{D}(\mathrm{VDR})$ je nuklearni receptor koji pripada familiji transkripcionih faktora.

Postoje različite tehnike za određivanje serumskog nivoa vitamina $D$, uz izvestan stepen varijacije rezultata. Stoga je važno obaviti standardizaciju tehnika radi ponovljivosti i uporedljivosti rezultata dobijenih u različitim istraživanjama. Vrednosti nivoa vitamina D od $20 \mathrm{ng} / \mathrm{ml}(50 \mathrm{nmol} / \mathrm{l})$ su potrebne za očuvanja koštanog i opšteg zdravlja, a poželjan referentni opseg je od 20 do $50 \mathrm{ng} / \mathrm{ml}$.

Podaci dobijeni u NHANES (National Health and Nutrition Examination Survey) ukazali su da nešto manje od četvrtine ispitanih adolescenata i odraslih američke populacije ima dovoljne koncentracije vitamina D (14). Novijom analizom ovog istraživanja je pokazano da je 
$61 \%$ ispitanika starosti od 1-21 godine imalo deficit vitamina D (16).

\section{Patogeneza bronhijalne astme}

Astma je hronična inflamatorna bolest disajnih puteva. Hronično inflamirani disajni putevi su hipereaktivni, dolazi do bronhoopstrukcije i limitiranog protoka vazduha kada su disajni putevi izlozeni različitim faktorima rizika. Astma nastaje kompleksnom intereakcijom genetskih i spoljašnjih uticaja, kao što je ekspozicija alergenima i infekcijama (20). U astmi dolazi do neadekvatnog imunskog odgovora sa dominacijom Th2 limfocita na uobičajne respiratorne alergene (15). Bronhijalnu astmu karakteriše bronhijalna hiperreaktivnost, a remodelovanje je udruženo sa izraženom bronhijalnom hipereaktivnošću (4). Remodelovanje disajnih puteva u astmi se povezuje sa steroidnom rezistencijom kod odraslih (10).

Bosse i kolege su in vitro ukazali da vitamin D povećava bioraspoloživost glukokortikoida u bronhijalnim glatkomišićnim ćelijama, sugerišući dalju potencijalnu ulogu vitamina $\mathrm{D}$ u prevenciji i lečenju astme. Ovi rezultati ukazuju da niži nivoi vitamina $\mathrm{D}$ mogu dovesti do proliferacije bronhijalnih glatkih mišića, oslobadjanja citokina i sledstveno remodelovanja disajnih puteva (3).

\section{VITAMIN D I IMUNSKI SISTEM}

Vitamin D ima uticaj na urođeni i stečeni imunitet (1). Ispoljava efekte na nekoliko tipova ćelija imunskog sistema: dendritičke ćelije (zrelost i tolerabilnost) (7), B i T ćelije (smanjuje proliferaciju Th1 i Th2 ćelija, Th1 i Th17 produkciju citokina, pokazuje doznozavisni efekat na Th2 odgovor (pojačanje/inibicija), a kod regulatornih T ćelija indukuje sintezu Il-10 i TGF B (26).

Vitamin D ima uticaj na bronhijalne glatkomišićne ćelije koje su značajne u bronhoopstrukciji u astmi: inhibira sintezu i oslobadjanje citokina, smanjuje inflamaciju, inhibira proliferaciju bronhijalnih glatko-mišićnih ćelija i remodelovanje, inhibira diferencijaciju, sazrevanje i aktivnost mastocita.

Genetičari su pretpostavili da se udruženost izmedju polimorfizma gena za VDR i genetske predispozicije za astmu, zasniva na činjenici da je gen za VDR mapiran na hromozomu 12q, blizu regiona koji se obično vezuje za astmu (21).

VDBP je serumski protein čija su imunomodulatorna svojstva vezana za pluća, najpre ogledaju u aktivaciji magrofaga i neutrofilnoj hemotaksi. Varijacije njegovog gena su udružene sa bolestima disajnih puteva, što ukazuje na njegovu potencijalnu ulogu u patogenez. Najveći broj dokaza za varijacije ovog gena se vezuju za HOBP, ali i moguću ulogu u astmi i bronhiektazijama (9).

ANTIVIRUSNA SVOJSTVA VITAMINA D I BRONHIJALNA ASTMA

Kod dece sa virusnim infekcijama i vizingom u ranom detinjstvu, najznačajniji prediktori razvoja astme do 6. godine su infekcije izazvane rinovirusima. Virusne infekcije su među najčešćim uzročnicima egzacerbacije astme.

Studija preseka Sabbetta i saradnika u kojoj su merene koncentracije vitamina D kod 198 zdravih odraslih osoba ukazala je da su osobe koje su imale koncentraciju 25(OH)D > $38 \mathrm{ng} / \mathrm{ml}$ imale značajno manji rizik od akutnih virusnih respiratornih infekcija (23).

Ginde i saradnici su sekundarnom analizom studije NHANES (Third National Health and Nutrition Examination Survey) u populaciji SAD u periodu od 1988. do 1994. ispitali povezanost nivoa 25(OH)D i skorašnje infekcije gornjeg respiratornog trakta kod 18883 učesnika starijih od 12 godina. Uočili su da su niži nivoi 25(OH)D nezavisno povezani sa skorašnjom infekcijom gornjeg respiratornog trakta, i da je ta povezanost bila izraženija kod osoba sa astmom i hroničnom opstruktivnom bolešću pluća (HOBP) (13).

Vitamin D deluje na katelicidin, humani peptid koji produkuju neutrofili, makrofagi, ćelije kože, respiratornog i digestivnog trakta koji ima široku antimikrobnu aktivnost (Gram-pozitivne i Gram-negativne bakterije, izvesni virusi i gljivice). U studiji Liu i saradnika pokazano je da je katelicidin neophodan za vitaminom D indukovanu antimikrobnu aktivnost protiv infekcije Mycobacterium tuberculosis (18).

\section{Vitamin D u bROnhijalnoj ASTMi}

Prevalencija astme, kao i nedostatak vitamina D, u stalnom su porastu poslednjih decenija (19). Zapažanja iz brojnih studija koja su se bavila povezanošću vitamina D i astme upućuju na pretpostavku da nedostatak vitamina $\mathrm{D}$ može biti važan činilac u patogenezi astme, stepenu kontrole i težine bolesti i terapijskom odgovoru.

Brem i saradnici su pratili vrednosti vitamina $\mathrm{D}$ u studiji sprovedenoj na 560 dece, starosti 6-14 godina obolelih od astme (287) i zdravih (273) u San Juan u Portoriku, nezavisno od rase, atopijske konstitucije i vremena provedenog na otvorenom. Deficit vitamina $D$ je bio izražen i kod dece koja boluju od astme (44\%) i kod zdrave dece (47\%). Deficit vitamina D je bio u korelaciji sa većom verovatnoćom za postojanje teške egzacerbacije u prethodnoj godini, pacijenti sa deficitom vitamina $\mathrm{D}$ su 
u većem broju imali udruženost sa atopijom i manjim odnosom $\mathrm{FEV}_{1} / \mathrm{FVC}$. Daljom podelom ispitanika prema atopijskoj konstituciji, povezanost izmedju deficita vitamina $\mathrm{D}$ i teške egzacerbacije je bila veća kod neatopičara. Izmereni deficit vitamina $\mathrm{D}$ je bio u pozitivnoj korelaciji sa jednom teškom egzacerbacijom astme kod dece Portorika, nezavisno od rasne pripadnosti, atopije i markera težine bolesti i stepena kontrole (6).

U studiji sprovedenoj 2009. godine u Kostariki, od 616 dece sa astmom starosti 6-14 godina, 28\% je imalo sniženu vrednost vitamina $\mathrm{D}(<30 \mathrm{ng} / \mathrm{ml})$. Regresiona analiza je pokazala da porast vrednosti vitamina $\mathrm{D}$ smanjuje verovatnoću za hospitalizacijom zbog astme, upotrebu antiinflamatrnih lekova i smanjenje markera alergijske inflamacije u prethodnoj godini (5).

Brem je u podstudiji CAMP (Childhood Asthma Management Program), u kojoj je učestvovalo 1024 dece Severne Amerike, uočio da je insuficijencija vitamina D češća kod dece sa blagom do umerenom astmom i udružena sa većom verovatnoćom za pojavu teške egzacerbacije tokom četvorogodišnjeg perioda. Black i saradnici su analizom podataka NHANES studije u kojoj je učestvovalo 144.091 ispitanika starijih od 20 godina kojima su merene serumske vrednosti vitamina $\mathrm{D}$ i spirometrijski parametri pluućne funkcije, utvrdili da postoji značajna korelacija izmedju serumskih vrednosti vitamiina $D$, $\mathrm{FEV}_{1}$ i FVC.

Studija preseka Lija i saradnika sprovedena je u Pekingu i obuhvatila 435 odraslih pacijenata sa novodijagnostikovanom astmom, starijih od 18 godina. Utvrđena je visoka prevalencija deficita vitamina D kod kineskih pacijenata sa astmom, ali bez značajne korelaciije nivoa vitamina $\mathrm{D}$ sa serumskim nivoom IgE, ali pozitvnom korelacijom sa parametrima plućne funkjcije $\left(\mathrm{FEV}_{1}\right.$, $\mathrm{FEV}_{1} / \mathrm{FVC}$ ) (17). Suthreland i saradnici su pokazali da su niže koncentracije viitamina $\mathrm{D}$ bile udružene sa smanjenom plućnom funkcijom, povećanom bronhijalnom hiperreaktivnošću, smanjenim odgovorom na kortikosteroide. ovi rezzultati ukazuje na mogući uticaj na- doknade vitamina $\mathrm{D}$ na stepen težine astme i terapijski odgovor (25).

Camargo i saradnici su ispitivali uticaj povećenog unosa vitamina $\mathrm{D}$ tokom trudnoće na mogući manji rizik od ponavljanih epizoda vizinga kod 1194 dece mlađe od 3 godine. Dokazali su da se smanjuje rizik od ponavljanja epizoda vizinga u ranom detinjstvu, koliko majka unosi više vitamina D (8). Gale i saradnici su zaključili da unos vitamina $\mathrm{D}$ u koncentracijama koje prelaze 75 $\mathrm{nmol} / \mathrm{l} \mathrm{u}$ trudnoći, ne utiče na intelekt deteta, psihološko zdravlje, kardiovaskularni sistem, ali da može povećati rizik od atopijskih bolesti (12). Devereux i saradnici su zaključili da povećan unos vitamina $\mathrm{D}$ u trudnoći može da smanji rizik od pojave vizinga u ranom detinjstvu (11).

\section{ZAKLJUČAK}

Iako je terapijska uloga vitamina $\mathrm{D}$ u rahitisu jasno dokazana, naučni podaci o njegovoj ulozi u bronhijalnoj astmi su još uvek kontradiktorni. Farmakološka osnova primene ovog vitamina se zasniva na njegovoj imunomodulatornoj ulozi u respiratornim infekcijama i zapaljenju u disajnim putevima. Aktuelna ispitivanja sa sve većim brojem dokaza o odnosu vitamina $\mathrm{D}$ i parametara plućne funkcije, egzacerbacija astme, alergijskih poremećaja i atopije, ukazuju na korist od njegove primene. Pitanje koje se nameće je: da li eventualna prevencija deficita vitamina $D$ ili adekvatna nadoknada mogu preokrenuti prirodni tok astme? Potrebna su dalja istraživanja u pravcu korišćenja vitamina $\mathrm{D}$ kao adjuvantne terapije kod bolesnika sa bronhijalnom astmom.

\section{NAPOMENA}

Rad je usmeno izložen na mini simpozijumu Vitamin D u plućnim i vanplućnim bolestima na 43. Simpozijumu Stremljenja i novine u medicine, Medicinski fakultet $\mathrm{u}$ Beogradu, 12.12.2014.

\section{Literatura:}

1. Adams JS, Hewison M. Unexpected actions of vitamin D: new perspectives on the regulation of innate and adaptive immunity. National Clinical Practice Endocrinology Metabolism 2008;4(2):80-90.

2. Black PN, Scragg R. Relationship between serum 25-hydroxyvitamin $\mathrm{d}$ and pulmonary function in the third national health and nutrition examination survey. Chest 2005;128(6):3792-8.

3. Bosse, Y., Maghni, K., and Hudson, T.J. 1alpha, 25-dihydroxy-vitamin D3 stimulation of bronchial smooth muscle cells induces autocrine, contractility, and remodeling processes. Physiol Genomics 2007; 29: 161-168.

4. Boulet L.P., Turcotte H., Laviolette M., Naud F., Bernier M.C., Martel S., Chakir J. Airway hyperresponsiveness, inflammation, and subepithelial collagen deposition in recently diagnosed versus long-standing mild asthma. Influence of inhaled corticosteroids. Am. J. Respir. Crit. Care Med 2000;162:1308-1313.

5. Brehm John M., Juan C. Celedón, Soto/Quiros ME et Al. Serum Vitamin D Levels and Markers of Severity of Childhood Asthma in Costa

Rica. Am J Respir Crit Care Med May 1, 2009; 179(9): 765-771.

6. Brehm , J. M., Acosta-Pérez, E., Klei, L., Roeder, K., Barmada, M., Boutaoui, N., ... Celedón, J. C. (2012). Vitamin D Insufficiency and Severe Asthma Exacerbations in Puerto Rican Children. American Journal of Respiratory and Critical Care Medicine 186(2), 140-146. doi:10.1164/rccm.201203-0431OC.

7. Brennan A, Katz DR, Nunn JD, et al. Dendritic cells from human tissues express receptors for the immunoregulatory vitamin D3 metabolite, dihydroxycholecalciferol. Immunology 1987;61(4):457-61.

8. Camargo CA, Jr., Rifas-Shiman SL, Litonjua AA, et al. Maternal intake of vitamin $\mathrm{D}$ during pregnancy and risk of recurrent wheeze in children at $3 \mathrm{y}$ of age. Am J Clin Nutr 2007;85(3):788-95.

9. Chishimba, L., Thickett, D.R., Stockley, R.A. et al. The vitamin D axis in the lung: a key role for vitamin D-binding protein. Thorax 2010; 65: 456-462.

10. Clifford, R.L. and Knox, A.J. Vitamin D - a new treatment for airway remodeling in asthma?. Br J Pharmacol 2009; 158: 1426-1428. 
11. Devereux G, Litonjua AA, Turner SW, et al. Maternal vitamin D intake during pregnancy and early childhood wheezing. Am J Clin Nutr 2007;85(3):853-9.

12. Gale CR, Robinson SM, Harvey NC, et al. Maternal vitamin D status during pregnancy and child outcomes. Eur J Clin Nutr 2008;62(1):6877.

13. Ginde AA, Mansbach JM, Camargo CA Jr Association between serum 25-hydroxyvitamin D level and upper respiratory tract infection in the Third National Health and Nutrition Examination Survey. Arch Intern Med 2009 Feb 23;169(4):384-90. doi: 10.1001/archinternmed.2008.560.

14. Ginde AA, Liu MC, Camargo CA., Jr. Demographic differences and trends of vitamin D insufficiency in the US population, 1988-2004. Arch Intern Med 2009;169(6):626-32.

15. Holgate S.T., Davies D.E., Powell R.M., Howarth P.H., Haitchi H.M., Holloway J.W. Local genetic and environmental factors in asthma disease pathogenesis: chronicity and persistence mechanisms. Eur Respir J 2007;29:793-803.

16. Kumar J, Muntner P, Kaskel FJ, Hailpern SM, Melamed ML. Prevalence and associations of 25-hydroxyvitamin D deficiency in US children: NHANES 2001-2004. Pediatrics 2009;124:e362-e70.

17. Li F. Peng M. Jiang L. Sun Q. Zhang K. Lian F. Litonjua A.A. Gao J. Gao X. Vitamin D Deficiency Is Associated with Decreased Lung Function in Chinese Adults with Asthma.Respiration 2011;81:469475 (DOI:10.1159/000322008).

18. Liu PT, Stenger S, Tang DH, Modlin RL. Cutting edge: vitamin D-mediated human antimicrobialactivity against Mycobacterium tuberculosis is dependent on the induction of cathelicidin. J Immunol 2007;179:2060-2063.
19. Litonjua AA, Weiss ST. Is vitamin D deficiency to blame for the asthma epidemic? J Allergy Clin Immunol 2007;120:1031-5.

20. Nelson H.S. The importance of allergens in the development of asthma and the persistence of symptoms. Dis. Mon. 2001;47:5-15.

21. Raby BA Lazarus R, Silverman EK, Lake S, Lange C, Wjst M, Weiss ST. Association of vitamin D receptor gene polymorphisms with childhood and adult asthma. Am J Respir Crit Care Med 2004 Nov 15;170(10):1057-65. Epub 2004 Jul 28.

22. Ross AC, Taylor CL, Yaktine AL, et al., editors. Dietary Reference Intakes for Calcium and Vitamin D. Washington (DC): National Academies Press (US); 2011. 3, Overview of Vitamin D.

23. Sabetta JR, DePetrillo P, Cipriani RJ, Smardin J, Burns LA, Landry ML. Serum 25-hydroxyvitamin $d$ and the incidence of acute viral respiratory tract infections in healthy adults. PLoS One 2010 Jun 14;5(6):e11088. doi: 10.1371/journal.pone.0011088.

24. Searing DA, Zhang Y, Murphy JR, Hauk PJ, Goleva E, Leung DY. Decreased serum vitamin D levels in children with asthma are associated with increased corticosteroid use. J Allergy Clin Immunol 2010;125:995-1000.

25. Sutherland ER, Goleva E, Jackson LP, Stevens AD, Leung DY. Vitamin D levels, lung function, and steroid response in adult asthma. Am J Respir Crit Care Med 2010;181:699-704.

26. Wittke A, Mahon BD, Weaver V, Cantorna MT. The targets of vitamin $\mathrm{D}$ depend on the differentiation and activation status of CD4 positive T cells. J Cell Biochem 2003;89(5):922-32. 